\title{
"Det måste väl vara bättre att granska sin historia än att måla över den?"
}

\section{Petronella Björn}

Det är nu snart elva år sedan ett fredsavtal slöts mellan katoliker och protestanter på Nordirland, men spåren efter konflikten är ännu tydliga i huvudstaden Belfast. I de buffertzoner där protestanter och katoliker under konfliktåren levde tillsammans byggdes det under 1970-talet upp murar som skulle skilja protestanter och katoliker åt. Idag har arbetet med att riva murarna påbörjats och shoppingcenter byggs upp i de gamla oroszonerna, men några av murarna står kvar i väntan på att rivas. Genom att låta människor handla tillsammans skall de mentala murarna rivas. Först därefter kan man riva dem i betong. Murarna står kvar som monumentala minnen av den blodiga historien, och att riva dem anser jag är bara att skrapa fernissan av det förflutna; det kollektiva minnet av händelserna kommer ändå att finnas kvar. På husgavlar finns stora väggtäckande bilder som man bara hittar i Belfast. Det är våldsromantiska skildringar av konflikten och motiv som skildrar kampen om historien och rätten att dela en historia. De mest våldsromantiska bilderna håller på att bytas ut eller målas över, men, som Joachim Vogel uttryckte det $\mathrm{i}$ ett resereportage i SVT:s program Gokväll den 12 mars 2009, det måste väl vara bättre att granska sin historia än att måla över den?

\section{Risken med att inte granska}

I kampen om historien kan man använda sig av bilder och monument för att rättfärdiga historiska anspråk eller olika politiska ideologier från de styrande skikten. I boken Historia som vapen hävdar Klas-Göran Karlsson att bilder av det förflutna påverkar grupper och individer i ett samhälle och därmed också blir faktorer som påverkar hela samhällsutvecklingen. När ett samhälle är under förändring kan historiska anspråk och olika typer av historiebruk bli ett problem. Det kollektiva minnet lagrar nämligen inte bara sådant vi själva upplevt utan också det som vi ärvt från tidigare generationer och för över till nästa generation (Karlsson 1999: 12f.). Roger Johansson framhåller i sin bok om Ådalen 1931 att bilder också kan tolkas som ett begrepp. En händelse som blir en markör eller ett vägskäl i den vidare samhällsutvecklingen hanteras i historieskrivningen som en begreppsbild, t.ex. bilden av Ådalen. Hur den bilden kommer att leva kvar i det kollektiva minnet beror mycket på hur och av vem den skildras (Johansson 2001: 25-27).

Konflikten på Nordirland blommade åter upp när en utbrytargrupp ur IRA, Real IRA, attackerade en brittisk arméförläggning den 7 mars 2009. Två brittiska soldater sköts till döds och fyra personer skadades. Real IRA tar på sig ansvaret för dådet. Ledare för samlingsregeringen med unionistpartiet DUP och representanter för Sinn Fein, IRA:s politiska gren, ser attacken som ett angrepp på fredsprocessen och fördömer det inträffade. Attacken beskrivs som den värsta sedan fredsavtalet undertecknades 1998. Folket på Nordirland har bestämt sig för att bevara freden och vill inte återgå till gamla tider. Onsdagen den 11 mars, bara några dagar efter attacken, demonstrerade protestanter och katoliker sida vid sida för att visa att majoriteten av dem står enade och stöder fredsprocessen. Jens Littorin skriver samma dag i en artikel på Dagens Nyheters nätupplaga att "även om den stora majoriteten på Nordirland motsätter sig våldet finns det en minoritet som försöker underblåsa det. Färskt klotter på Belfasts murar visade uppmuntran för utbrytargrupperna, och någon hade under onsdagen eldat upp blommor som personer lagt på en gata för att hedra 
den mördade polismannen." Man kan här tänka sig att det från statsmaktens sida finns en vilja att måla över detta klotter i väntan på att denna del av muren skall rivas. En risk finns då, anser jag, att man kan underblåsa den känsla av minoritet och utanförskap som eventuellt leder till nya attacker.

\section{Rätten att granska}

Jag hävdar att bilder av historien måste granskas av historiker för att förhindra att de förvanskas. För om de inte granskas av historiker eller om vissa bilder blir övermålade finns risken att exempelvis media eller organisationer med särskilda intressen väljer bilder som förtydligar vissa händelser. Vem har rätt att göra det urvalet? Flera historiker använder sig av termen historiskt minne. Johansson talar om historiskt minne som vår uppfattning av vad som utspelat sig. Om man retuscherar det minnet kan enskildheter bli klarare än vad de var vid den ursprungliga upplevelsen (Johansson 2001: 26, 82). Karlsson är inne på samma spår och menar att minnas är att återvinna historien. Likheten mellan historia och kollektivt minne består i att det "finns en social och kulturell kontext som avgör vad som är värt att återvinna", men också i hur man ska återvinna historien samt vad som ska stanna kvar i "glömskans dunkel" (Karlsson 1999: 31). I förmedlandet av bilder, både som begrepp och rent faktiska, fyller historikern en viktig funktion. Vilken bild som ska visas eller vilken berättelse som ska återges bestäms många gånger av historikerns, eller berättarens, eget kollektiva historiska minne och därmed hennes eller hans historiemedvetande. Därför finns det inte en bild av en händelse, utan flera. I en tid av förändring träder historiens underströmmar fram, de som skapar och återskapar en egen klasskultur, och tvingar fram ställningstaganden från det övriga samhället därför att historia som nedtecknade berättelser inte alltid är synlig (Johansson 2001: 43). Därför måste alla sidor eller bilder av historien bli synliga för alla grupper, oavsett om man tillhör de styrande i samhället eller en subkultur i förändring. Hur man sedan väljer att synliggöra historien eller hur man väljer att använda den blir nästa fråga eftersom "den historiska kunskapen i sig själv inte förändrar världen, medan däremot människors bruk av den kan göra det" (Karlsson 1999: 26).

\section{Granskning innebär att man får en bredare bild av historien}

Reaktionerna på dödsskjutningarna på Nordirland den 7 mars 2009 kan tolkas utifrån ett kortare och längre perspektiv. I det korta perspektivet, som vi inte helt sett verkningarna av ännu, resulterar de förhoppningsvis i fängelsestraff för de inblandade men också ett nytt avstamp i fredsprocessen och det arbete som politikerna i samstyret är måna om att få fortsätta. Det har också visat sig i fredsaktioner och demonstrationer mot våldet. I ett längre perspektiv kan man peka på betydelsen av att folket har skrivit in sig i en större historia; ideologiska utgångspunkter och historieskrivning har flätats samman. Folket använder sig här av olika bilder, mentala och monumentala, för att förmedla en historia till eftervärlden, eller, för att använda Johanssons ord, "Vissa händelser får ett starkt symbolvärde genom att de förmår svara på vårt behov av att se mening och sammanhang i en verklighet som annars kan framstå som både ogenomtränglig och fragmentarisk" (Johansson 2001: 27). Själva utformningen av demonstrationen och reaktionerna efter attacken kommer också att på längre sikt skapa ett slags tolkning inför eftervärlden. Fotografier och berättelser förmedlar en bild av män och kvinnor som står enade, en bild av fredskampens Nordirland i mars 2009. Byt inte ut den mot någon tidigare bild utan låt bägge bilderna existera $i$ en samverkan för att få en bredare bild av historien! En historia som alla kan identifiera sig med. 


\section{Referenser}

Johansson, Roger, 2001, Kampen om historien: Ådalen 1931. Sociala konflikter, historiemedvetande och historiebruk 1931-2000. Stockholm: Hjalmarsson \& Högberg.

Karlsson, Klas-Göran, 1999, Historia som vapen. Stockholm: Natur och Kultur.

http://www.dn.se/nyheter/varlden/soldater-ihjalskjutna-i-nordirland-1.815837 avläst 2009-03-17.

http://www.dn.se/nyheter/varlden/tusentals-demonstrerade-mot- valdet-1.818647 avläst 2009-03-17. 